\title{
The Behaviour of Some Rose Cultivars of Different Origin as Cut Flowers in Nutritive Solutions
}

\author{
Vasile LAZĂR ${ }^{1)}$, Rodica SIMA ${ }^{\left.1^{*}\right)}$, Tincuţa GOCAN ${ }^{11}$, Ilona ORBAN ${ }^{1)}$ \\ 1)University of Agricultural Sciences and Veterinary Medicine, 3-5 Mănăștur Street, Cluj-Napoca \\ 400372, Romania \\ ${ }^{*}$ Corresponding author, e-mail: rodiganea@yahoo.com
}

Bulletin UASVM Horticulture 71(2) / 2014

Print ISSN 1843-5254, Electronic ISSN 1843-5394

DOI:10.15835/buasvmcn-hort:10643

\begin{abstract}
The researches done between the years 2012-2013 at Horticultural products technology Department of Horticulture Faculty of UASVM Cluj-Napoca followed the influence of preservative solution on the decorative period in vase of four indigenous and four imported (Dutch origin) rose cultivars. The obtained results shown that the interaction of preservative solution with cultivar pointed out the 'Avalance' and 'Samba' Romanian cultivars which in Chrysal preservative solution recorded very significant positive differences in comparison with control ('Merci' cultivar), for all the three studied characteristics (diameter of floral bud, the aspect of floral bud and the aspect of leaves on the floral stem).
\end{abstract}

Keywords: characteristics, cultivar, preservative solution, roses, vase life

\section{INTRODUCTION}

Roses occupy an important place among ornamental plants cultivated in field and protected spaces (Wagner, 2010) thanks to their morphological and ornamental characteristics (elegance of flowers, richness of colours and, sometimes, even the perfume). Regardless of cultivation place, roses provide substantial incomes both for farmers and for traders because they are appreciated and required by consumers to carnations detriment, which were the only ones sold out of season, shortly ago.

The assortment diversification and the improvement of culture technologies (high planting density $11,100-13,300 \mathrm{pl} \cdot \mathrm{ha}^{-1}$, planting distances of 3/0.25-0.30 m, mechanization of the land preparation and pests control etc. - Wagner, 2013) come to support rose indigenous producers to extend rose cultures in field and to reduce massive imports of cut flowers from Western European countries, taking into account the high expenses of rose greenhouse cultures.

An important quality of some rose cultivars is represented by decorative period in vase, which increased as average at two weeks (Lazăr et al., 2010).

\section{MATERIALS AND METHODS}

The experiment was conducted between the years 2012-2013 in the frame of Horticultural products technology laboratory of Horticulture Faculty from UASVM Cluj-Napoca. The research followed the influence of preservative solution on the decorative period in vase of four indigenous (Iris-Cluj greenhouses) and four imported Dutch rose cultivars (greenhouse crops). The following experimental factors presented in table 1 were studied.

From the two experimental factors combination, 40 experimental variants resulted. The studied biological material was relatively uniform as development stage (half-open bud). The experimental variants were placed in similar conditions of light and temperature with flats. During storage period the cut of the bottom of stem was daily refreshed and the level of preservative solution was filled up to $500 \mathrm{ml}$ with tap water. The observations were done at each 48 hours during 
Tab.1. The experimental factors and their graduations

\begin{tabular}{ccc}
\hline A Factor (preservative solutions) & \multicolumn{2}{c}{ B Factor (cultivar) } \\
\hline Tap water (control) $-\mathrm{S}_{1}$ & Indigenous cultivars & Imported cultivars \\
\hline $\begin{array}{c}\text { Amăriuței Alexandrina (1987) recipe }(3 \% \\
\text { Sucrose, 0,02\% Sodium chloride, 0,01\% } \\
\text { Potassium sulphate }-\mathrm{S}_{2}\end{array}$ & 'Merci' (control) & 'Freedom' (control) \\
\hline Chrysal $-\mathrm{S}_{3}$ & 'Good times' & 'Tara' \\
\hline Flower Food $-\mathrm{S}_{4}$ & 'Avalance' & 'Avalance' \\
\hline Fleur 'Eau $-\mathrm{S}_{5}$ & 'Samba' & 'Samba' \\
\hline
\end{tabular}

storage period and followed many characteristics, out of which three main characteristics regarding the decorative value are presented in this paper: diameter of floral bud ( $\mathrm{mm}$ ), the aspect of floral bud and the aspect of leaves on the floral stem. For all these characteristics were accorded scores from 1 to 3, as follows: 1 - very good aspect; 2 good aspect; 3 - satisfactory aspect. The obtained results were statistically analyzed by the ANOVA test.

\section{RESULTS AND DISCUSSIONS}

The unilateral influence of preservative solution on the floral bud diameter of cut rose flowers was relatively small in all tested cultivars (Tab. 2)

While the diameter of floral bud at indigenous cultivars had not recorded statistically significant differences in comparison with control (tap water), for Dutch cultivars in Flower Food preservative solution a distinct significant increase of floral bud diameter of $26.36 \mathrm{~mm}$ in comparison with control was observed. The obtained results were similar with respect to unilateral influence of preservative solution on the aspect of floral bud. Thus, at Dutch cultivars in Flower Food preservative solution the obtained differences in comparison with control were very closed by LSD of $5 \%$. Considering the indigenous cultivars in three of those five variants of preservative solutions negative but not statistically significant differences in comparison with control were recorded while only in Chrysal preservative solution the difference was positive but also not statistically significant.

The influence of preservative solution on the aspect of leaves on the floral stem revealed small positive and negative differences in comparison with control for Dutch cultivars and negative significant differences for indigenous cultivars in Amăriuței and Flower Food preservative solutions.
The data presented in table 3 emphasize that the tested cultivars differently influenced the analyzed characteristics.

All indigenous cultivars recorded very significant increases of the diameter of floral bud in comparison with control (,Merci' cultivar) while only ,Avalance' among imported cultivars revealed very significant increase of diameter of floral bud in comparison with control (,Freedom' cultivar).

The unilateral influence of cultivar on the aspect of floral bud for indigenous cultivars revealed similar results with the influence of cultivar on the diameter of floral bud. The variation with the cultivar in the floral bud aspect of the imported cultivars revealed positive distinct significant differences at ,Avalance' and 'Tara' and positive significant difference at 'Samba' in comparison with control.

The unilateral influence of cultivar determined positive significant differences of the aspect of leaves on the floral stem for all imported cultivars while at 'Good times' and 'Avalance' indigenous cultivars positive significant respectively at,Samba' distinct significant differences were recorded.

The combined influence of cultivar and preservative solution on the studied characteristics of Romanian roses determined different effects (Tab. 4). Thus, the diameter of floral bud recorded higher values than control in all preservative solutions, inclusively in tap water. The best results were obtained in Flower Food solution with very significant increases of floral bud diameter of all studied cultivars in comparison with control. Similar very significant increases of floral bud diameter in Chrysal, Fleur 'Eau solutions and in tap water for ,Avalance' and ,Samba' cultivars and in Amăriuței solution for 'Samba' cultivar were recorded. 
Tab. 2 The influence of preservative solution on the analyzed characteristics of cut rose flowers

\begin{tabular}{|c|c|c|c|c|c|c|}
\hline \multicolumn{7}{|c|}{ The influence of preservative solution on the diameter of floral bud } \\
\hline \multirow[b]{2}{*}{$\begin{array}{c}\text { Preservative } \\
\text { solutions }\end{array}$} & \multicolumn{3}{|c|}{ Indigenous cultivars } & \multicolumn{3}{|c|}{ Imported cultivars } \\
\hline & $\begin{array}{l}\text { Average } \\
\text { diameter } \\
(\mathrm{mm})\end{array}$ & $\begin{array}{c}\text { Difference in } \\
\text { comparison } \\
\text { with control } \\
\quad( \pm)\end{array}$ & $\begin{array}{l}\text { Significance } \\
\text { of } \\
\text { differences }\end{array}$ & $\begin{array}{l}\text { Average } \\
\text { diameter } \\
(\mathrm{mm})\end{array}$ & $\begin{array}{l}\text { Difference in } \\
\text { comparison } \\
\text { with control } \\
\quad( \pm)\end{array}$ & $\begin{array}{c}\text { Significance } \\
\text { of } \\
\text { differences }\end{array}$ \\
\hline $\mathrm{S}_{1}$ (control) & 67.33 & - & - & 30.89 & - & - \\
\hline $\mathrm{S}_{2}$ & 62.75 & -4.58 & - & 22.04 & -8.85 & - \\
\hline $\mathrm{S}_{3}$ & 71.81 & 4.50 & - & 41.44 & 10.55 & - \\
\hline $\mathrm{S}_{4}$ & 66.67 & 1.34 & - & 57.26 & 26.37 & $* *$ \\
\hline \multirow[t]{4}{*}{$\mathrm{S}_{5}$} & 69.42 & 2.09 & - & 43.12 & 12.33 & - \\
\hline & LSD 5\% & & 16.12 & \multicolumn{2}{|c|}{ LSD $5 \%$} & 14.71 \\
\hline & LSD $1 \%$ & & 23.45 & \multicolumn{2}{|c|}{ LSD 1\% } & 21.40 \\
\hline & LSD $0.1 \%$ & & 35.18 & \multicolumn{2}{|c|}{ LSD $0.1 \%$} & 32.30 \\
\hline \multicolumn{7}{|c|}{ The influence of preservative solution on the floral bud aspect } \\
\hline & \multicolumn{3}{|c|}{ Indigenous cultivars } & \multicolumn{3}{|c|}{ Imported cultivars } \\
\hline $\begin{array}{l}\text { Preservative } \\
\text { solutions }\end{array}$ & $\begin{array}{l}\text { Average } \\
\text { score }\end{array}$ & $\begin{array}{c}\text { Difference in } \\
\text { comparison } \\
\text { with control } \\
( \pm)\end{array}$ & $\begin{array}{l}\text { Significance } \\
\text { of } \\
\text { differences }\end{array}$ & $\begin{array}{l}\text { Average } \\
\text { score }\end{array}$ & $\begin{array}{l}\text { Difference in } \\
\text { mparison with } \\
\text { control }( \pm)\end{array}$ & $\begin{array}{c}\text { Significance } \\
\text { of } \\
\text { differences }\end{array}$ \\
\hline $\mathrm{S}_{1}$ (control) & 1.75 & - & - & 0.83 & - & - \\
\hline $\mathrm{S}_{2}$ & 1.32 & -0.43 & - & 0.66 & -0.17 & - \\
\hline $\mathrm{S}_{3}$ & 1.95 & 0.20 & - & 1.06 & 0.23 & - \\
\hline $\mathrm{S}_{4}$ & 1.50 & -0.25 & - & 1.35 & 0.52 & $(*)$ \\
\hline \multirow[t]{4}{*}{$\mathrm{S}_{5}$} & 1.58 & -0.17 & - & 1.10 & 0.27 & - \\
\hline & LSD 5\% & & 0.79 & \multicolumn{2}{|c|}{ LSD 5\% } & 0.53 \\
\hline & LSD 1\% & & 1.14 & \multicolumn{2}{|c|}{ LSD 1\% } & 0.77 \\
\hline & LSD $0.1 \%$ & & 1.71 & \multicolumn{2}{|c|}{ LSD $0.1 \%$} & 1.16 \\
\hline
\end{tabular}

The influence of preservative solution on the aspect of leaves on the floral stem

\begin{tabular}{ccccccc}
\hline & \multicolumn{3}{c}{ Indigenous cultivars } & \multicolumn{3}{c}{ Imported cultivars } \\
\cline { 2 - 7 } $\begin{array}{c}\text { Preservative } \\
\text { solutions }\end{array}$ & $\begin{array}{c}\text { Average } \\
\text { score }\end{array}$ & $\begin{array}{c}\text { Difference in } \\
\text { comparison } \\
\text { with control } \\
( \pm)\end{array}$ & $\begin{array}{c}\text { Significance } \\
\text { of } \\
\text { differences }\end{array}$ & $\begin{array}{c}\text { Average } \\
\text { score }\end{array}$ & $\begin{array}{c}\text { Difference in } \\
\text { comparison with } \\
\text { control }( \pm)\end{array}$ & $\begin{array}{c}\text { Significance } \\
\text { of } \\
\text { differences }\end{array}$ \\
\hline $\mathrm{S}_{1}$ (control) & 1.61 & - & - & 1.14 & - & - \\
\hline $\mathrm{S}_{2}$ & 1.33 & -0.28 & 0 & 0.82 & -0.32 & - \\
\hline $\mathrm{S}_{3}$ & 1.72 & 0.11 & - & 1.27 & 0.13 & - \\
\hline $\mathrm{S}_{4}$ & 1.32 & -0.29 & 0 & 1.59 & 0.45 & - \\
\hline $\mathrm{S}_{5}$ & 1.44 & -0.17 & - & 1.33 & 0.19 & - \\
\hline & LSD 5\% & & 0.23 & & LSD 5\% & 0.91 \\
\hline & LSD 1\% & & 0.33 & & LSD 1\% & 1.33 \\
\hline & LSD 0.1\% & & 0.50 & & LSD 0.1\% & 1.99 \\
\hline
\end{tabular}


Tab. 3. The influence of cultivar on the studied characteristics of cut rose flowers

The influence of cultivar on the diameter of floral bud

\begin{tabular}{|c|c|c|c|c|c|c|c|}
\hline $\begin{array}{l}\text { Indigenous } \\
\text { cultivars }\end{array}$ & $\begin{array}{c}\text { Average } \\
\text { diameter } \\
(\mathrm{mm})\end{array}$ & $\begin{array}{l}\text { Difference in } \\
\text { comparison } \\
\text { with control } \\
\qquad( \pm)\end{array}$ & $\begin{array}{l}\text { Significance } \\
\text { of differences }\end{array}$ & Imported cultivars & $\begin{array}{l}\text { Average } \\
\text { diameter } \\
(\mathrm{mm})\end{array}$ & $\begin{array}{c}\text { Difference in } \\
\text { comparison } \\
\text { with control } \\
( \pm)\end{array}$ & $\begin{array}{l}\text { Significance } \\
\text { of differences }\end{array}$ \\
\hline 'Merci' (control) & 50.67 & - & - & $\begin{array}{l}\text { 'Freedom' } \\
\text { (control) }\end{array}$ & 40.40 & - & - \\
\hline 'Good times' & 65.40 & 14.13 & $* * *$ & 'Tara' & 46.13 & 5.73 & - \\
\hline 'Avalance' & 76.13 & 25.46 & $* * *$ & 'Avalance' & 61.43 & 21.03 & $* *$ \\
\hline 'Samba' & 79.80 & 29.13 & $* * *$ & 'Samba' & 46.79 & 6.39 & - \\
\hline & LSD 5\% & & 6.43 & & LSD 5\% & & 13.01 \\
\hline & LSD 1\% & & 8.66 & & LSD 1\% & & 17.54 \\
\hline & LSD $0.1 \%$ & & 11.50 & & SD $0.1 \%$ & & 21.44 \\
\hline \multicolumn{8}{|c|}{ The influence of cultivar on the aspect of floral bud } \\
\hline $\begin{array}{l}\text { Indigenous } \\
\text { cultivars }\end{array}$ & $\begin{array}{l}\text { Average } \\
\text { score }\end{array}$ & $\begin{array}{c}\text { Difference in } \\
\text { comparison } \\
\text { with control } \\
( \pm)\end{array}$ & $\begin{array}{l}\text { Significance } \\
\text { of differences }\end{array}$ & Imported cultivars & $\begin{array}{l}\text { Average } \\
\text { score }\end{array}$ & $\begin{array}{c}\text { Difference in } \\
\text { comparison } \\
\text { with control } \\
( \pm)\end{array}$ & $\begin{array}{l}\text { Significance } \\
\text { of differences }\end{array}$ \\
\hline $\begin{array}{c}\text { 'Merci' } \\
\text { (control) }\end{array}$ & 0.93 & - & - & $\begin{array}{l}\text { 'Freedom' } \\
\text { (control) }\end{array}$ & 1.01 & - & - \\
\hline 'Good times' & 1.62 & 0.69 & $* * *$ & 'Tara' & 1.33 & 0.32 & $* *$ \\
\hline 'Avalance' & 1.92 & 0.99 & $* * *$ & 'Avalance' & 1.38 & 0.37 & $* *$ \\
\hline 'Samba' & 1.87 & 0.4 & $* * *$ & 'Samba' & 1.28 & 0.27 & $*$ \\
\hline & LSD 5\% & & 0.39 & & LSD 5\% & & 0.21 \\
\hline & LSD $1 \%$ & & 0.52 & & LSD $1 \%$ & & 0.29 \\
\hline & LSD $0.1 \%$ & & 0.69 & & SD $0.1 \%$ & & 0.38 \\
\hline
\end{tabular}

The influence of cultivar on the aspect of leaves on the floral stem

\begin{tabular}{|c|c|c|c|c|c|c|c|}
\hline $\begin{array}{l}\text { Indigenous } \\
\text { cultivars }\end{array}$ & $\begin{array}{l}\text { Average } \\
\text { score }\end{array}$ & $\begin{array}{c}\text { Difference in } \\
\text { comparison } \\
\text { with control } \\
( \pm)\end{array}$ & $\begin{array}{l}\text { Significance of } \\
\text { differences }\end{array}$ & Imported cultivars & $\begin{array}{c}\text { Average } \\
\text { score }\end{array}$ & $\begin{array}{c}\text { Difference in } \\
\text { comparison } \\
\text { with control } \\
( \pm)\end{array}$ & $\begin{array}{l}\text { Significance } \\
\text { of differences }\end{array}$ \\
\hline $\begin{array}{c}\text { 'Merci' } \\
\text { (control) }\end{array}$ & 0.91 & - & - & $\begin{array}{l}\text { 'Freedom' } \\
\text { (control) }\end{array}$ & 0.98 & - & - \\
\hline 'Good times' & 1.66 & 0.75 & $*$ & 'Tara' & 1.30 & 0.32 & $*$ \\
\hline 'Avalance' & 1.64 & 0.73 & $*$ & 'Avalance' & 1.32 & 0.34 & $*$ \\
\hline 'Samba' & 1.73 & 0.82 & $* *$ & 'Samba' & 1.31 & 0.33 & $*$ \\
\hline & LSD 5\% & & 0.61 & \multicolumn{3}{|c|}{ LSD 5\% } & 0.26 \\
\hline & LSD 1\% & & 0.82 & \multicolumn{3}{|c|}{ LSD 1\% } & 0.35 \\
\hline & LSD $0.1 \%$ & & 1.09 & \multicolumn{3}{|c|}{ LSD $0.1 \%$} & 0.47 \\
\hline
\end{tabular}




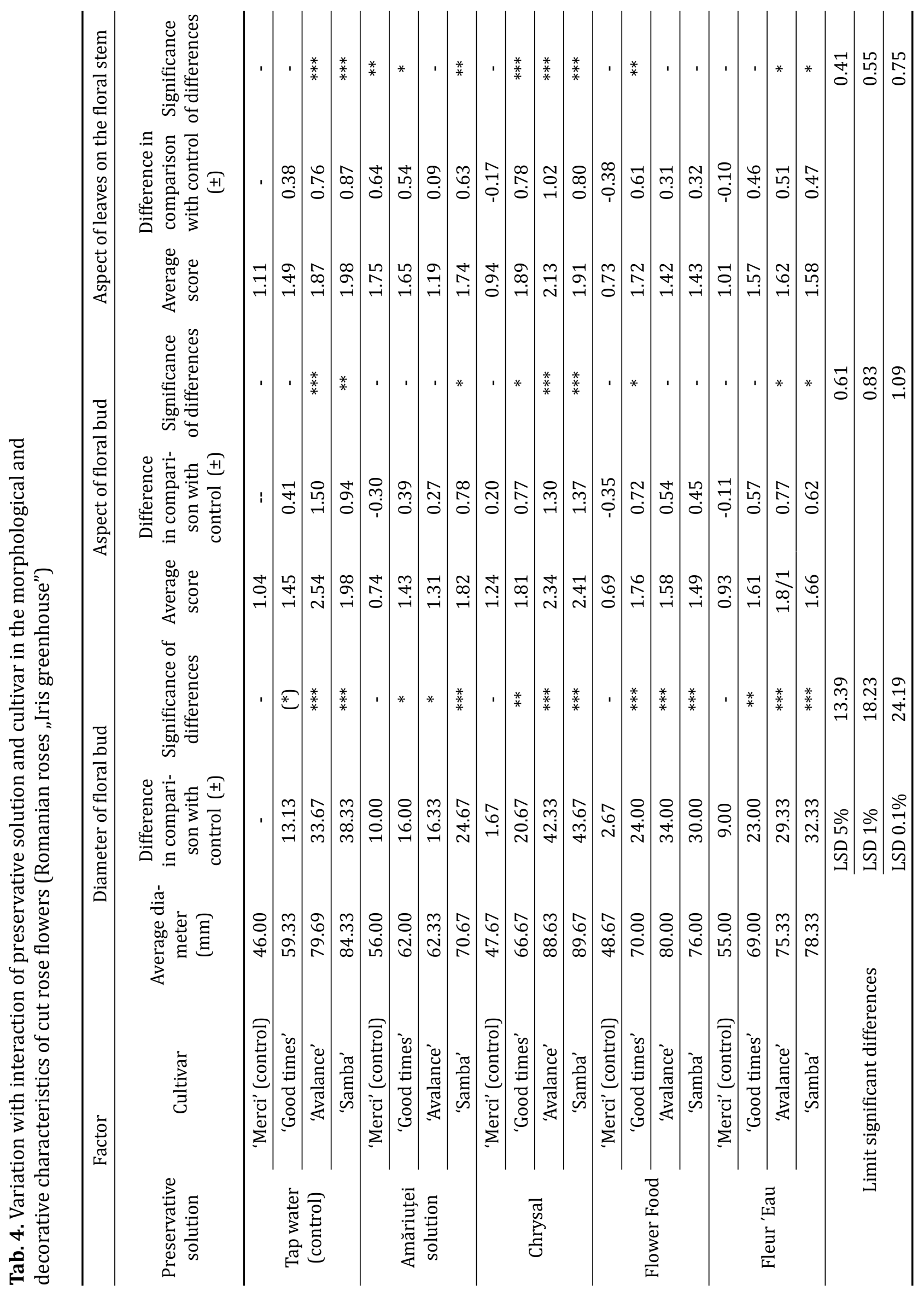




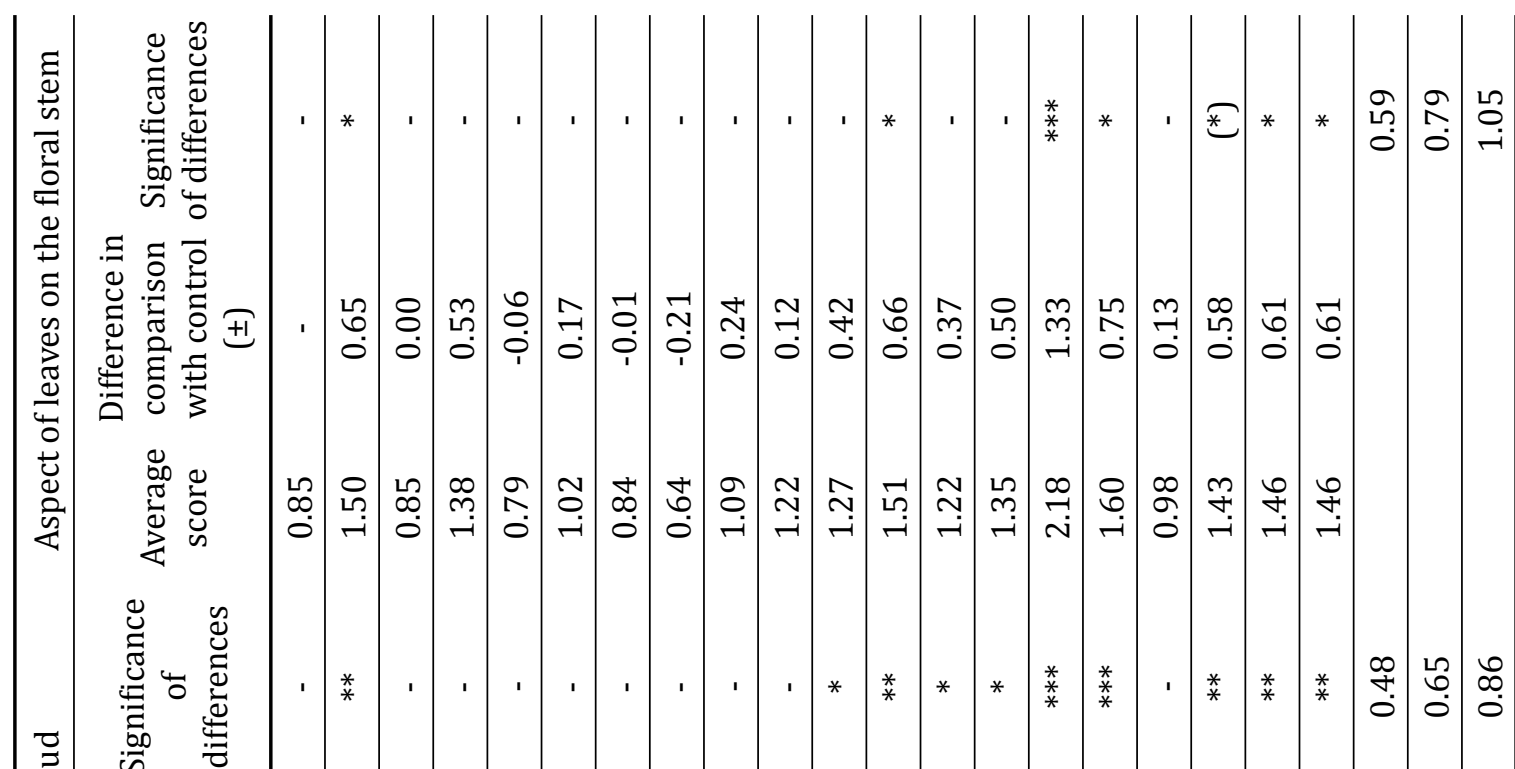

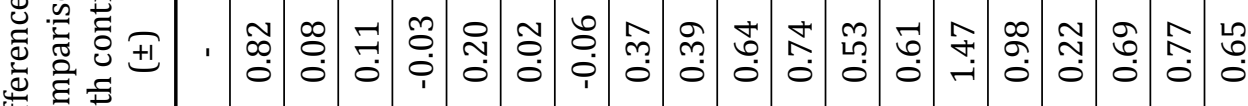
究 范

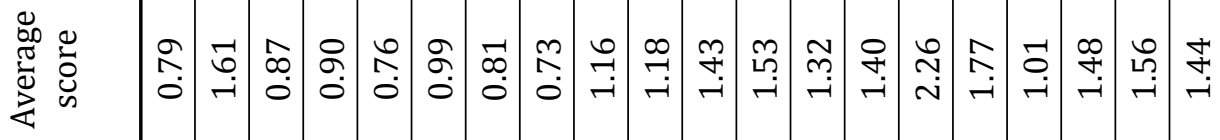

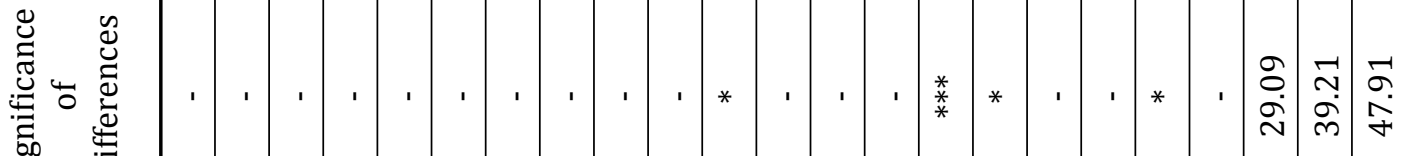

$\pi$

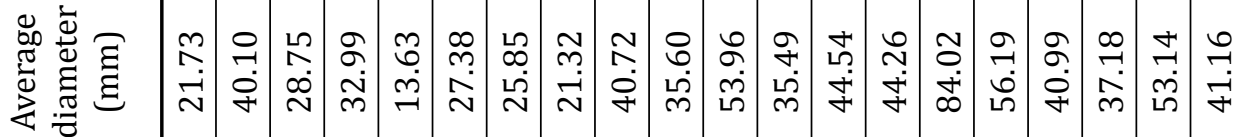

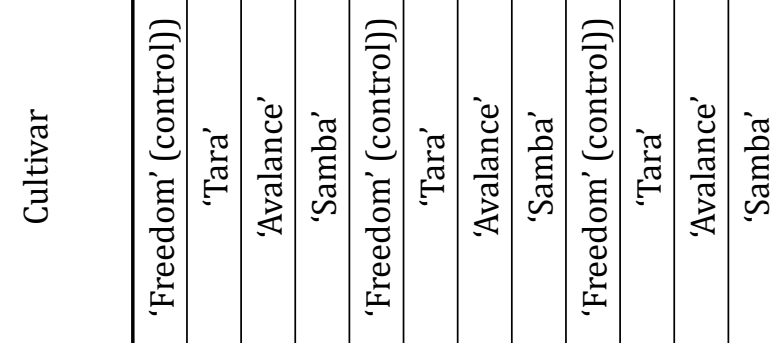

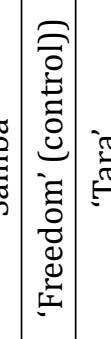
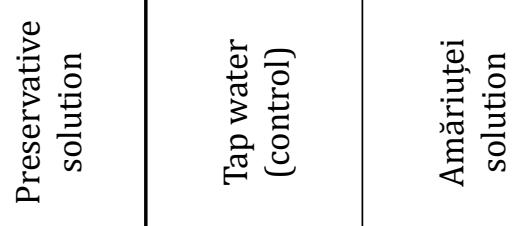

苞
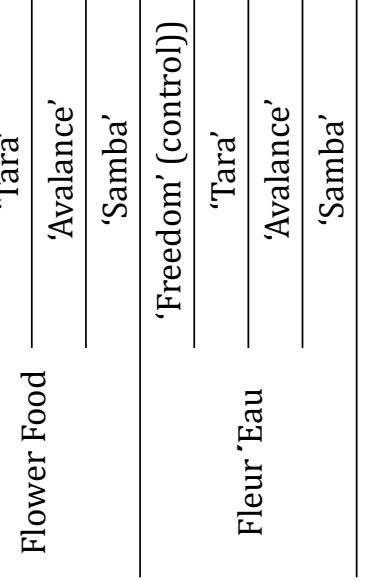

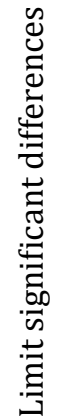


Tab. 6. The influence of preservative solution and cultivar on the vase life of cut rose flowers

\begin{tabular}{|c|c|c|c|c|}
\hline & Factor & & & \\
\hline Preservative solution & Indigenous cultivars & (days) & Duten cuitivars & (days) \\
\hline & 'Merci' (control) & 8.0 & 'Freedom' (control) & 7.0 \\
\hline & 'Good times' & 10.5 & 'Tara' & 6.0 \\
\hline Tap water (control) & 'Avalance' & 12.5 & 'Avalance' & 7.0 \\
\hline & 'Samba' & 16.0 & 'Samba' & 11.0 \\
\hline & Average & 10.25 & Average & 7.75 \\
\hline & 'Merci' (control) & 6.5 & 'Freedom' (control) & 5.0 \\
\hline 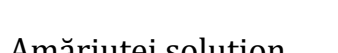 & 'Good times' & 13.5 & 'Tara' & 6.0 \\
\hline Amariuțel soiution & 'Avalance' & 11.0 & 'Avalance' & 6.0 \\
\hline & 'Samba' & 15.0 & 'Samba' & 7.0 \\
\hline & Average & 11.50 & Average & 6.00 \\
\hline & 'Merci' (control) & 9.0 & 'Freedom' (control) & 8.0 \\
\hline Chrucal o o o & 'Good times' & 15.0 & 'Tara' & 8.0 \\
\hline Cnrysal & 'Avalance' & 19.5 & 'Avalance' & 10.5 \\
\hline & 'Samba' & 19.5 & 'Samba' & 9.5 \\
\hline & Average & 15.75 & Average & 9.00 \\
\hline & 'Merci' (control) & 9.0 & 'Freedom' (control) & 10.5 \\
\hline & 'Good times' & 11.0 & 'Tara' & 9.5 \\
\hline Flower Food & 'Avalance' & 18.0 & 'Avalance' & 11.5 \\
\hline & 'Samba' & 14.0 & 'Samba' & 13.0 \\
\hline & Average & 13.00 & Average & 11.13 \\
\hline & 'Merci' (control) & 9.0 & 'Freedom' (control) & 8.5 \\
\hline & 'Good times' & 12.5 & 'Tara' & 9.5 \\
\hline Fleur Eau & 'Avalance' & 15.2 & 'Avalance' & 10.5 \\
\hline & 'Samba' & 13.5 & 'Samba' & 10.5 \\
\hline & Average & 12.63 & Average & 9.75 \\
\hline
\end{tabular}

The combined influence of the two experimental factors on the aspect of floral bud was less evidently. However, the best results were obtained in Chrysal preservative solution and in tap water for ,Avalance' and ,Samba' cultivars.

Regarding the aspect of leaves on the floral stem very significant positive differences under de combined influence of preservative solution and cultivar for all studied cultivars in Crysal solution and for ,Avalance' and 'Samba' in tap water were recorded.

Analysing the combined influence of the two experimental factors on Dutch cultivars the 'Avalance' cultivar in Flower Food solution with very significant positive differences of all studied characteristics has to be remarked (Tab. 5). In the same preservative solution 'Samba' cultivar revealed very significant positive difference for the aspect of floral bud and positive significant differences both for the diameter of floral bud and for the aspect of leaves on floral stem in comparison with control. Similar results obtained with 'Samba' in Flower Food solution were revealed by 'Avalance' in Fleur 'Eau solution with the mention that for the aspect of floral bud the obtained difference in comparison with control was distinctly significant.

The data presented in table 6 point out that the preservative solutions, the tested cultivars as well as their origins influenced the vase life of cut rose flowers.

Based on the obtained results the preservation of cut rose flowers in the solutions recommended by traders extends the vase life in average with 
2.38-5.50 days for indigenous cultivars and with 1.25-3.38 days for imported cultivars.

The studied cultivars react differently at preservation in nutritive solutions, ,Avalance' and 'Samba' being remarked regardless the preservative solution type or their origins.

The third factor which can extend or reduce the vase life of cut rose flowers is the origin of biological material used in the experiment. Thus, the vase life increases in average with 1.87-6.75 days at Romanian roses in comparison with imported roses, regardless the preservative solution type or the cultivar.

\section{CONCLUSIONS}

Analysing the results of research regarding the influence of preservative solution on the vase life of four indigenous rose cultivars and four imported Dutch rose cultivars, the following conclusions and recommendations can be drawn: - the unilateral influence of preservative solution on the three studied morphological and ornamental characteristics of cut rose flowers was relatively poor, the only one lightly affected characteristic being the aspect of leaves on the floral stem at Romanian cultivars;
- the analysed cultivars act differently at preservation in nutritive solutions, the 'Avalance' cultivar being remarked with significant positive differences of all studied characteristics in comparison with control, regardless its origin;

- the interaction of preservative solution and cultivar pointed out ,Avalance' and 'Samba' indigenous cultivars which in Crysal solution revealed very significant positive differences in comparison with control for all the three studied characteristics;

- for those who have the possibility to purchase Romanian roses, ,Avalance' and 'Samba' cultivars with an extension of 19.5 days of vase life in Crysal solution are recommended.

\section{REFERENCES}

1. Amăriuței Al (1987). Păstrarea florilor tăiate. Ed. Ceres, București.

2. Lazăr V, Cantor M, Sima R, Gocan T, Rad G (2010). Researches concerning the beaviour of some rose cultivars as cut flowers in nutritive solutions. Bul. USAMV Cluj-Napoca 67(1):368-374.

3. Wagner St (2010). Trandafirul cu parfum. Ed. Napoca Stat, Cluj-Napoca.

4. Wagner St (2013). Revista Rosarium nr. 2 (anul XXIII - nr. 46):8-13. 